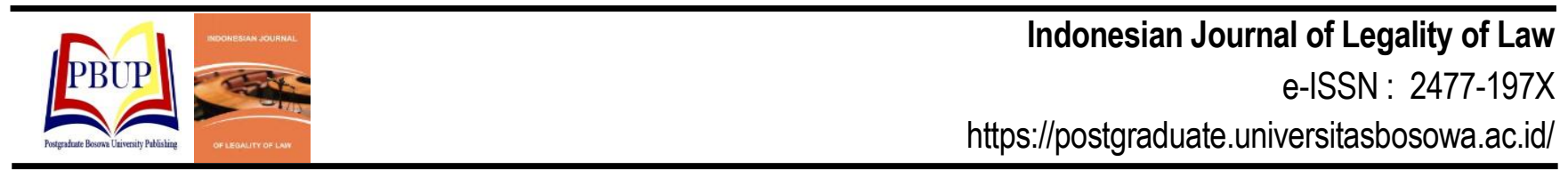

\title{
PENEGAKAN HUKUM TINDAK PIDANA POLITIK UANG DALAM PEMILIHAN UMUM TAHUN 2019 DI KABUPATEN POLEWALI
}

\author{
Law Enforcement of Money Politics in the 2019 General Election in Polewali Regency \\ Usman $^{1}$, Marwan Mas ${ }^{2}$, Ruslang Renggong ${ }^{2}$ \\ ${ }^{1}$ Badan Pengawas Pemilihan Umum, Kabupten Polewali \\ ${ }^{2}$ Program Studi Ilmu Hukum Program Pascasarjana Universitas Bosowa \\ Email: usman.usma6668@gmail.com
}

Diterima: 10 Januari 2021/Disetujui: 01 Juni 2021

\begin{abstract}
ABSTRAK
Ditenggarai lemahnya penegakan hukum terhadap pelanggaran politik uang yang terjadi pada Pemilu 2019 menjadi isu yang mengemuka, termasuk di Kabupaten Polewali Mandar. Peran pengawasan, penegakan dan penindakan, sebagaimana yang diatur dalam Undang-undang Nomor Nomor 7 tahun 2017 tentang Pemilihan Umum dan Peraturan Bawaslu Peraturan Bawaslu Nomor 31 Tahun 2018 tentang Sentra Penegakan Hukum Terpadu (Gakkumdu) memuat sejumlah ketentuan yang mengatur mekanisme dan tata cara penegakan hukum terhadap pelanggaran politik uang tersebut. Metode yang digunakan dalam penelitian ini adalah, penelitian empiris yang mengkaji regulasi atau peraturan perundang-undangan dalam praktik penegakan hukum terhadap dugaan pelanggaran politik uang pada penyelenggaraan Pemilu Tahun 2019. Kesimpulan penelitian menunjukkan bahwa, terdapat 3 (tiga) kasus dugaan pelanggaran politik uang pada Pemilu Tahun 2019 di Kabupaten Polewali Mandar yang semestinya melewati 9 (sembilan) tahapan dalam kenyataannya hanya sampai pada tahapan ketiga yakni, rapat pleno pengawas Pemilu. Hal itu dikarenakan adanya ketidak sepahaman di dalam tim Sentra Gakkumdu dengan Bawaslu Kabupaten Polewali Mandar. Adapun kendala dalam penengakan hukum terhadap dugaan pidana politik uang sangat terkait dengan struktur hukum, substansi hukum dan budaya hukum sebagaimana fakta dan temuan lapangan. Karenanya, penelitian ini merekomendasikan, ke depan pidana Pemilu tidak lagi ditangani oleh Bawaslu, tetapi dimasukkan sebagai pidana umum. Dan jika sentra Gakkumdu tetap dipertahankan keberadaannya, hendaknya diberi kewenangan tambahan yakni, melakukan penahanan terhadap terduga pelaku politik uang, agar tidak terbuka ruang mengkodisikan saksi dugaan politik uang. Termasuk pentingnya pembentukan peradilan khusus Pemilu agar perbedaan pandangan atas kasus dugaan politik uang dapat diminimalisir.
\end{abstract}

Kata Kunci: Penindakan Pidana; Politik Uang; Pemilihan Umum

\begin{abstract}
The indication of the weak law enforcement against money politics violations that occurred in the 2019 Election has become an emerging issue, including in Polewali Mandar Regency. The role of supervision and enforcement, as regulated in Law Number 7 of 2017 concerning General Elections and Bawaslu Regulation Number 31 of 2018 concerning Sentra Penegakan Hukum Terpadu (Gakkumdu) contains a number of provisions governing the mechanisms and procedures for law enforcement against such violations of money politics. The method used in this research is empirical research that examines regulations or statutory regulations in law enforcement practices against suspected violations of money politics at the 2019 Election. The research conclusion shows that, there were 3 (three) cases of alleged violations of money politics in the 2019 Election in Polewali Mandar Regency which should have passed 9 (nine) stages but in reality only reached the third stage, namely, the Election supervisor plenary meeting. It was due to the lack of Understanding on the Sentra Gakkumdu with Bawaslu Polewali Mandar. The obstacles in law enforcement against allegations of money politics crime are closely related to the legal structure, legal substance and legal culture as well as facts and field findings. Therefore, this research recommends that in the future election crimes will no longer be handled by Bawaslu, but be included as general crimes. And if the Sentra Gakkumdu is maintained, it should be given additional authority, namely, detaining suspected money politics actors, so that there is no room to codify witnesses for alleged money politics. This includes the importance of establishing a special election court so that differences in views on suspected cases of money politics can be minimized.
\end{abstract}

Keywords: Criminal Prosecution, Money Politics, General Election 


\section{PENDAHULUAN}

Pemilihan Umum (Pemilu) di Indonesia dilaksanakan berdasarkan asas langsung, umum, bebas, rahasia, jujur dan adil yang berpedoman pada Pancasila dan Undang-Undang Dasar Negara Republik Indonesia (UUD NRI) Tahun 1945. Pemilihan Umum diselenggarakan untuk memilih Anggota Dewan Perwakilan Rakyat, Dewan Perwakilan Daerah dan Pemilihan Presiden dan Wakil Presiden dalam masa jabatan lima tahun. Lawrence Meir Friedman, mengatakan bahwa berhasil tidaknya penegakan hukum tergantung tiga unsur sistem hukum, yakni struktur hukum (struktur of law), subtansi hukum (substance of the law), dan budaya hukum (legal culture). Struktur hukum menyangkut aparat penegak hukum, subtansi hukum meliputi perangkat perundangundangan dan budaya hukum merupakan hukum yang hidup (living law) yang dianut dalam suatu masyarakat.

Memahami pengertian dari teori M. Friedman di atas, dapat ditarik kesimpulan bahwa ketiga unsur hukum tersebut harus berjalan seiring agar hukum dapat ditegakan untuk memenuhi keadilan sehingga masyarakat dapat merasakan kemamfaatan hukum itu sendiri. Hukum dan masyarakat suatu hal yang tidak bisa berdiri sendiri, ibarat dua sisi mata uang yang tidak dapat dipisahkan. Berlakunya hukum itu berlangsung dalam suatu tatanan sosial, karena itu hukum harus ditempatkan sebagai kerangka proses yang terus berkembang seiring dengan tuntutan kemajuan masyarakat. M. Friedman lebih lanjut menjelaskan bahwa, pertama-tama sistem hukum mempunyai struktur, sistem hukum terus berubah, namun bagian-bagian sistem hukum itu berubah dalam kecepatan yang berbeda, dan setiap bagian berubah tidak secepat bagian tertentu lainnya. Artinya terdapat pola jangka panjang yang berkesinambungan yaitu aspek sistem yang berada di sini kemarin atau bahkan pada abad yang terakhir, akan berada di situ dalam jangka panjang. Inilah yang disebut struktur sistem hukum (Taufiq, 2014).

Bara Nusa Setia, mengemukakan bahwa struktur hukum yang menentukan bisa atau tidaknya hukum itu dilaksanakn dengan baik, sturktur hukum yang dimaksud adalah berdasarkan Undang-Undang No. 8 tahun 1981 meliputi Lembaga Kepolisian, Lembaga Kejaksaan, Lembaga Pengadilan dan lembaga pelaksanaan pidana (lapas). Secara singkat dapat dikatakan bahwa komponen yang bersifat struktural ini memungkinkan masyarakat untuk mengharapkan bagaimana suatu sistem hukum itu seharusnya bekererja (law in the hooks). Sebagai contoh Frietman menjelaskan struktur Mahkamah Agung di Amerika Serikat. Mahkamah Agung di Amerika Serikat berdiri sejak akhir abad kedelapan belas, sarnpai pada abad keduapuluh satu ini kebiasaan kerjanya berubah secara perlahan. Struktur dari hukum terdiri dari unsur: jumlah dan ukuran pengadilan, yurisdiksinya, dan cara mengajukan upaya hukum.

Struktur juga meliputi bagaimana badan legislatif diatur jumlah anggotanya. Dari sini dapat disimpulkan struktur dari sistem hukurn merupakan kerangka bentuk yang permanen dari sistem hukum yang menjaga proses tetap berada di dalam batas - batasnya (Friedman, 2001). Secara sederhana, lembaga dapat pula diartikan sebagai organ atau badan kenegaraan yang mengemban fungsi menyelenggarakan pemerintahan negara. Organ negara atau badan negara itulah yang diberikan tugas dan fungsi dalam sistem penyelenggara negara. Lembaga - lembaga negara itu harus bersinergi dan bekerja sama untuk mencapai tujuan bersama yang ditetapkan dalam mkonstitusi dan peraturan perundang-undangan di bawahnya. Marwan Mas, mengemukakan Eksistensi lembaga negara tidak dapat dipisahkan dari keberadaan suatu negara yang berdaulat, yang merupakan alat kelengkapan yang ada dalam suatu negara. Dalam teori hukum tata negara, suatu negara disebut berdaulat apabila memenuhi empat syarat, yaitu ada wilayah tertentu luas dan batasny, ada rakyat, ada pemerintahan dan dapat pengakuan negara lain sebagai negara berdaulat. Begitu Pula, eksistensi lembaga negara selaku alat kelengkapan negara berdasarkan teori klasik negara meliputi, kekuasan legislative, eksekutif, dan yudikatif. Setiap alat kelengkapan negara tersebut bias memiliki orang-orang lain untuk membantu melaksanakan tugas dan fungsinya (Mas, 2018).

Kabupaten Polewali Mandar merupakan daerah penduduk terbanyak di wilayah Provinsi Sulawesi Barat dengan jumlah Daftar Pemilih Tetap (DPT) pada Pemulu tahun 2019 sebanyak 303.864 yang tersebar di 16 Kecamatan. Resiko dan tantangan yang timbul dalam pelaksanaan sistem demokrasi pada saat pemilihan umum masih selalu saja muncul berbagai macam isu tentang lemahnya penegakan hukum, pada penyelenggaraan tahapan pemilu berlangsung. Adapun pelanggaran yang sering terjadi adalah pelanggaran administrasi dan tindak pidana Pemilu yang terjadi pada setiap tahapan pelaksanaannya, terutama pelanggaran politik uang atau yang sering disebut Money Politics.

Politik uang (Money Politics) pada Pemilihan Umum di daerah Kabupaten Polewali Mandar menjadi alat untuk meraih atau memperoleh suara pemilih jika ingin memenangkan sebuah kontestasi pemilihan. Dalam transaksi politik uang terjadi suatu persekongkolan antara calon dengan peserta, dan sebagian besar masyarakat menjadikannya sebagai sesuatu yang dinanti-nantikan disetiap pemilihan jika tidak ada uang maka tidak dipilih, karena mereka berpandangan bahwa siapa yang memberikan uang maka itulah yang dipilih.

Kabupaten Polewali Mandar merupakan daerah yang masih memiliki angka kemisikinan yang cukup banyak, yaitu sekitar 69.680 jiwa atau sekitar 15,97 \% dari jumlah penduduk Kabupaten Polewali Mandar. Hal inilah yang membuat para calon DPR, DPD, Presiden dan Wakil Presiden dan DPRD sangat gampang mempengaruhi masyarakat dalam transaksi politik dengan perjanjian memberikan suara kepada para calon. Transaksi politik uang ini biasanya terjadi pada masa kampanye yang dilakukan oleh calon peserta Pemilu ketika menyampaikan visi, misi, dan program kepada masyarakat disertai dengan iming-iming atau janji agar dipilih pada masa pemungutan suara, kampanye tersebut juga dilakasanakan pada tahap masa tenang dimana pada masa ini merupakan saat-saat yang krusial karena mendekati hari pemungutan suara. Pada tahap masa tenang, politik uang yang dilakukan peserta pemilu yang oleh masyarakat menyebutnya sebagai serangan fajar karena dilakukan pada dini hari menjelang fajar, dimana intensitas transaksi politik uang dapat meningkat karena para calon peserta pemilu saling berlombalomba melakukan berbagai cara agar memperoleh suara sebanyak-banyaknya, hal ini sudah sering terjadi pada setiap pemilihan, sehingga sebagian besar masyarakat merasa hal tersebut menjadi sesuatu yang lumrah.

Perilaku politik uang menjadi budaya yang telah mengakar sejak pemilu 2004 dengan sistem pemilihan 
proporsional terbuka dengan suara terbanyak, sampai saat pelaksanan pemilu 2019 justru makin marak dengan persaingan antar calon makin ketat pula. Dampak negatif dari politik uang sangat berpengaruh pada jalannya roda pemerintahan sebab pemimpin yang terpilih yang menggunakan politik uang biasanya dalam menjalankan pemerintahannya berusaha bagaimana caranya agar bisa mengembalikan modal yang telah dikeluarkan sebagai biaya politik untuk membeli suara rakyat pada saat pemilihan, sehingga menyebabkan banyak kebijakan yang dijalankan bukan berdasarkan kepentingan umum (kepentingan rakyat), namun lebih kepada tujuan kepentingan pribadi atau golongan. Semakin besar dana yang dikucurkan pada saat pemilihan, maka semakin lebih besar pula dana yang akan di kembalikan dengan cara korupsi.

Praktik politik uang hingga saat ini menjadi momok pada setiap pelaksanaan Pemilu termasuk pemilu 2019. Mencegah terjadinya politik uang (Money Politics) merupakan tantangan besar yang dihadapi oleh Bawaslu dan jajarannya sebagai Pengawas pada pemilu dan Pilkada agar untuk meminimalisir terjadinya praktik politik uang. Untuk melakukan pengawasan terdapat beberapa kendala dalam pencegahannya yang dihadapi Pengawas Pemilu yang pertama enggannya masyarakat untuk melaporkan dan menjadi saksi bila terjadi pelanggaran politik uang karena tidak ingin direpotkan dengan urusan prosedur. Warga masyarakat merasa takut melaporkan karena dalam Undang-Undangan Pemilu tidak dijelaskan secara rinci bagaimana perlindungan hukum bagi saksi atau pelapor ketika melaporkan adanya politik uang. Bahkan pada proses persidangan nantinya, saksi atau pelapor diwajibkan hadir sehingga masyarakat lebih memilih diam akibat tidak ingin direpotkan untuk selalu ikut sidang pengadilan.

Kemudian karena banyaknya celah hukum dalam regulasi perundang-Undangan Pemilu dan Pilkada, hingga ruang ini dimanfaatkan oleh para pelaku praktik politik uang melakukan aksi untuk meraih suara rakyat. Melihat dari kondisi inilah, maka kehadiran Bawaslu sebagai institusi negara beran untuk mencegah dan menindak terhadap setiap yang diduga melakukan pelanggaran terhadap UndangUndang Pemilu. Terlepas dari tugas, fungsi, dan wewenang Bawaslu sebagai lembaga Pengawas pemilihan dalam melakukan pencegahan, pengawasan, dan penindakan pelanggaran Pemilu, peran aktif masyarakat sangat penting untuk menjadikan hasil Pemilu atau Pilkada yang baik dan bersih dari praktik politik uang harus didukung pula pemerintah untuk mengawal jalannya penyelenggaraan Pemilu dan Pilkada. Telah menjadi pekerjaan rumah bagi Bawaslu dan Jajarannya agar bagaimana meningkatkan kesadaran masyarakat dalam mencegah terjadinya politik uang dengan meningkatkan partisipasi masyarakat terutama bagi pemilih pemula untuk mensosialisaikan agar berperan aktif dalam mensukseskan pelaksanaan Pemilu.

Bawaslu Kabupaten Polewali Mandar pada Pemilu tahun 2019 telah menangani dan memproses dugaan pelanggaran polirtik uang, akan tetapi taksatupun bisa dilimpahkan kasusnya ketingkat penuntutan di pengadilan. Berangkat dari uraian tersebut, maka penulis memandang perlu mengkaji lebih dalam tentang maraknya isu politik uang, dan bagaimana sehingga pelaku politik uang tidak dapat diproses lebih lanjut di Kabupaten Polewali Mandar sehingga penulis akan melakukan penelitian dengan judul "Penindakan Pelanggaran Pidana Politik Uang pada Pemilu tahun 2019 di Kabupaten Polewali Mandar".

\section{METODE}

a Jenis Penelitian

Penelitian ini menggunakan pendekatan empiris, penelitian empiris ini dilakukan dengan cara mengkaji hukum dalam realitas di lapangan atau kenyataan di dalam masyarakat. Pada penelitian empiris, yang diteliti pada awalnya ialah data sekunder yang kemudian dilanjutkan dengan penelitian terhadap data primer dilapangan atau terhadap masyarakat. Sedangkan penelitian deskriptif yaitu dimaksudkan untuk memberikan data yang seteliti mungkin tentang manusia, keadaan atau gejala-gejala lainnya.

b Lokasi Penelitian

Lokasi penelitaian di kantor Badan Pengawas Pemilihan Umum (Bawaslu) Kabupaten Polewali Mandar yang berkedudukan di Kota Polewali. Selain itu, penulis juga akan mengumpulkan data skunder dan informasi terkait penelitian pada beberapa instasi yang terlibat lansung dalam pelaksanaan tahapan pemilihan umum tahun 2019 seperti; Komisi Pemilhan Umum Daerah Kabupaten Polewali Mandar, Kejaksaan Kabupaten Polewali Mandar, Kepolisian Resor Kabupaten Polewali Mandar.

c Jenis Data Jenis data meliputi:

1. Data Primer

Data primer merupakan data dari sejumlah keterangan atau fakta yang diperoleh penulis secara langsung melalui penelitian lapangan dari lokasi penelitian yang telah disebutkan di atas, yaitu berupa hasil wawancara ataupun keterangan dari pihak pengawas Pemilu, penyidik, penuntut umum, dan hakim di Kabupaten Polewali Mandar.

2. Data Skunder

Data sekunder tidak digeroleh secara langsung dari lokasi lapangan, tetapi data itu berkaitan dengan data yang relevan dan mendukung masalah yang diteliti. Data sekunder ini berupa:

a. Undang-Undang Dasar 1945.

b. Undang-Undang Negara Republik Indonesia No. 7Tahun 2017 tentang Pemilu.

c. Undang-Undang Negara Republik Indonesia No. 8 Tahun 1981 tentang Kitab Undang-Undang Hukum Acara Pidana (KUHAP).

d. Peraturan Pemerintah No. 27 Tahun 1983 tentang Pelaksanaan Kitab Undang-Undang Hukum Acara Pidana.

d Teknik Pengumpulan Data

Teknik pengumpulan data sebagai berikut:

1. Teknik Wawancara (Interview)

Penelitian ini penulis menggunakan berdasarkan sejumlah pertanyaan yang telah disusun mendetail dengan tidak menggunakan jawaban alternatif, dalam bentuk komunikasi verbal, semacarn percakapan yang bertujuan untuk memperoleh infonnasi. Para pihak yang akan terlibat dalarn wawancara ini adalah Pengawas Pemilu, Penyidik dari Kepolisian,,Penuntut Umum dari Kejaksaan, Komisi Bawaslu Kabupaten Polewali Mandar, para Tokoh Politik, dan Budayawan yang berkompeten dalam wilayah Kabupaten Polewali Mandar.

2. Studi Kepustakaan

Studi kepustakaan dilakukan dengan membaca, mengkaji, dan mempelajari substansi dari isi bahan 
hukum, literatur tertentu dan dokumen-dokumen resmi serta peraturan perundang-undangan yang berhubungan dengan topik permasalahan yang diteliti, yaitu:

a. Undang-Undang Dasar 1945, Undang-Undang Nomor 7 tahun 2017 yang menjadi landasan Pemilu tahun 2019.

b. Undang-Undang Nomor 152 Tahun 2011 tentang Kepolisian Negara Republik Indonesia.

c. Undang-Undang Nomor2 Tahun 2011 tentang Partai Politik.

d. Undang-Undang Nomor 8 Tahun 1981 tentang Kitab Undang-Undang Hukum Acara Pidana (KUHAP).

e. Peraturan Pemerintah No. 27 Tahun 1983 tentang Pelaksanaan Kitab Undang-Undang Hukum Acara Pidana.

3. Melakukan diskusi kelompok (Focus Group Discussion) FGD. Salah satu teknik yang digunakan penulis dalam penelitian kualitatfi ini adalah melaksanakan FGD yang pada hakekatnya merupakan sebuah wawancara mendalam dengan sejumlah orang yang dipilih dalam diskusi, FGD merupakan diskusi kelompok terarah.

e Teknik Analisis Data

Teknik analisis data kualitatif dengan menggunakan metode interaktif. Analisis data ialah langkah selanjutnya untuk mengolah hasil penelitian menjadi suatu laporan, hal ini merupakan kegiatan mengumpulkan data yang kemudian dikerjakan dan dimanfaatkan sedemikian rupa sehingga dapat menyimpulkan persoalan yang diajukan dalam menyusun hasil penelitian. Menurut Afrizal, bahwa ada dua tahap analisis data dalam penelitian kualitatif yaitu: pertama pada tahap pengumpulan data dan oleh sebab itu analisis data dilakukan di lapangan; kedua dilakukan ketika penulisan laporan. Jadi dengan demikian, analisis data dalam penelitian kualitatif mulai dari tahap pengumpulan data sampai tahap penulisan laporan. Oleh sebab itulah, analisa data dalam penelitian kualitatif sering disebut sebagai analisis berkelanjutan (ongoing analysis) (Afrizal, 2017).

Analisis data kualitatif terdiri dari alur kegiatan yang dilakukan penulis secara bersamaan yaitu: rduksi data, sajian data, dan penarikan kesimpulan. Reduksi data merupakan proses pemilihan, pemfokusan, penyederhanaan, abstraksi, dan transformasi terhadap data kasar yang diperoleh dari catatan lapangan. Penyajian data dilakukan dengan menyajikan sekumpulan informasi yang tersusun dalam suatu kesatuan bentuk yang disederhanakan, selektif dalam konfigurasi yang mudah dipakai sehingga memberi kemungkinan adanya pengambilan keputusan (Taufiq, 2014).

\section{HASIL DAN PEMBAHASAN}

\subsection{Bentuk Penegakan Hukum Terhadap Pelaku Tindak Pidana Politik Uang dalam Pemilihan Umum Tahun 2019 di Kabupaten Polewali Mandar}

Berdasarkan fakta lapangan, politik uang dalam penyelenggaraan Pemilu masih terjadi, karenanya penegakan hukum terhadap politik uang menjadi sesuatu yang niscaya ditegakkan, sebagaimana mandat regulasi kewenangan yang melekat pada Bawaslu, berikut ini akan dijelaskan tahapan proses penanganan pelanggaran Pemilu Bawaslu Kabupaten Polewali Mandar sebagai hasil temuan di lapangan penelitian.

Terdapat 3 (tiga) kasus dugaan politik uang pada Pemilu tahun 2019 di Kabupaten Polewali Mandar yang diproses. Dari tiga kasus dugaan politik uang tersebut, semuanya merupakan temuan Bawaslu Kabupaten Polewali Mandar yang dalam proses penanganannya dilaksanakan dalam satu atap secara terpadu oleh Gakkumdu dengan merujuk kepada asas, keadilan,kepastian, kemanfaatan, persamaan di depan hukum (equality before the law), praduga tidak bersalah, dan legalitas dengan berpedoman kepada proses dan mekanisme penyelesaian tindak pidana Pemilu sebagaimana yang diamanatkan melalui Peraturan Bawaslu Nomor 31 Tahun 2018.

\section{a. Kasus Tindak Pidana Politik Uang pada Pemilu Tahun 2019}

Pada penyelenggaraan Pemilu Tahun 2019, Bawaslu Kabupaten Polewali Mandar telah menangani dan memproses 3 (tiga) kasus dugaan tindak pidana politik uang yang selanjutnya, berdasarkan hasil penelitian dapat diuraikan sebagai berikut:

1) Kasus Temuan nomor 003/TM/PL/KAB./30.05/IV/2019, diregistrasi tanggal 16 April 2019

a. Pasal yang disangkakan

Pasal 523 ayat (1) "Setiap pelaksana, peserta, dan/atau tim kampamnye Pemilu yang dengan sengaja menjanjikan atau memberikan uang atau materi lainnya sebagai imbalan kepada peserta Kampanye Pemilu secara langsung ataupun tidak langsung sebagaimana dimaksud dalam pasal 280 ayat (1) huruf j dipidana dengan pidana penjara paling lama 2 (dua) tahun dan denda paling banyak Rp. 24.000.000,00 (Dua Puluh Empat Juta Rupiah)"

b. Syarat Formil: Pelapor, Terlapor, Batas Waktu Temuan (belum daluwarsa), Kesesuaian tanda tangan pada formulir laporan dengan KTP elektronik.

c. Syarat Materil: Peristiwa dan uraian kejadian, Tempat kejadian terjadi, Saksi, Bukti. Syarat laporan dan temuan apakah syarat formil dan syarat materil dalam kasus temuan Bawaslu dengan Nomor: 003/TM/PL/Kab/ 30.05/IV/2019 oleh Bawaslu Kabupaten Polewali Mandar dinyatakan memenuhi syarat.

d. Uraian Kejadian: Pada hari Jumat tanggal 12 April 2019 sekitar pukul 11:00 Wita, saya selaku pengawas TPS di Desa Sumarrang Kecamatan Campalagian, melihat salah seorang calon anggota Legislatif DPRD Provinsi Sulawesi Barat berinisial HS dari Partai Golkar nomor urut tujuh bersama seorang timnya datang ke rumah MA, salah satu warga. Saat itu, HS datang dengan menggunakan mobil. Saya yang melihatnya, kemudian mengikuti HS hingga ke rumah MA. Di rumah MA, HS kemudian tampak memberikan sejumlah uang pecahan seratus ribuan disertai ajakan untuk mendukung dan memilihnya. Menyaksikan itu, kemudian saya mengabadikan peristiwa itu merekamnya dengan menggunakan kamera telepon seluluer. Saat mengetahui, saya merekam kejadian itu dengan menggunakan kamera telepon selulure itu, kemudian dihapus oleh orang yang datang bersama dengan HS. Hal itu dilakukan setelah HS mengetahui saya adalah slah seorang pengawas TPS di Desa Sumarrang Kecamatan Campalagian. Saat itu, HS tampak terlihat panik kemudian memohon kepada saya untuk tidak menyampaikan hal itu ke Panwaslu Kecamatan Campalagian, dengan alasan bahwa kejadian pemberian itu hanyalah merupakan biaya politik. 
e. Bukti-Bukti: Uang Pecahan Seratus Ribu sebanyak dua Lembar dengan nomor seri: BCG 328352; ODC 546150; dan Telepon seluler

f. Tanggapan Unsur Kepolisian: Tidak terpenuhi unsur pasal 523 ayat (1) Undang-Undang Pemilihan Umum Tahun 2017

g. Tanggapan Unsur Kejaksaan

- Belum tergambar dalam keterangan saksi-saksi unsur mens rea dari HS sebab terputus dari keterangan saksi untuk mengaitkan kepada HS

- Dari keterangan saksi-saksi tidak tergambar adanya kegiatan kampanye yang dilakukan oleh MA (terlapor) sebagaimna yang di maksud dalam pasal 280 ayat 1 Undang-Undang nomor 7 tahun 2017 tentang Pemilihan Umum.

- Tidak ada saksi yang mengetahui dan menyaksikan serta melihat langsung dan dapat membuktikan bahwa, MA (terlapor) telah melakukan kegiatan larangan kampanye terkait menyampaian visi-misi untuk HS salah satu calon legislatif tahun 2019, perbuatan terlapor dan HS belum memenuhi pasal yang disangkakan sehingga belum dapat dinaikkan ke tahap penyidikan

h. Tanggapan Unsur Bawaslu Polewali Mandar: Syarat Formal dan Materil suatu kasus telah terpenuhi, dalam klarifikasi terhadap saksi dan terlapor ditemukan bukti bahwa terlapor benar telah memberikan uang $\mathrm{Rp}$. 100.000,_ (seratus ribu rupiah) kepada masyarakat sebagai imbalan kepada peserta kampanye pemilu secara langsung ataupun tidak langsung, sesuai dengan alat bukti yang tertuang dalam pasal 184 KUHAP telah didapatkan alat bukti berupa: alat bukti saksi, keterangan ahli dan petunjuk;

i. Kesimpulan: Perbuatan terlapor Sdr. MA belum terpenuhi untuk pembuktian dalam pasal 523 ayat (1) Undang-Undang Pemilihan Umum Tahun 2017 sehingga belum dapat ditingkatkan ke tahap penyidikan;

j. Rekomendasi: Agar dilakukan pemeriksaan terhadap para saksi dan terlapor guna pemenuhan unsur pasal yang dikenakan kepada terlapor;

b. Kasus

Temuan 008/TM/PL/KAB/30.05/IV/2019 diregistrasi pada tanggal 22 April 2019

a. Pasal yang disangkakan: Pasal 523 ayat (2) "Setiap pelaksana, peserta, dan/atau tim Kampanye Pemilunyang dengan sengaja pada Masa Tenang menjanjikan atau memberikan imbalan uang atau materi lainnya kepadaPemilih secara langsung ataupun tidak langsung sebagai mana dimaksud dalam Pasal 278 ayat (2) dipidana dengan pidana penjara paling lama 4 (empat) tahun dan denda paling banyak Rp48.000.000,00 (empat puluh delapan juta rupiah)."

b. Syarat Formil: Pelapor, Terlapor, Batas Waktu Temuan (belum kadaluwarsa), Kesesuaian tanda tangan pada formulir laporan dengan KTP Elektronik.

c. Syarat Materil: Peristiwa dan uraian kejadian, Tempat kejadian terjadi, Saksi, Bukti. Syarat laporan dan temuan apakah syarat formil dan syarat materil dalam kasus temuan Bawaslu dengan nomor: 003/TM/PL/Kab/ 30.05/IV/2019 oleh Bawalu Kabupaten Polewali Mandar dinyatakan memenuhi syarat atau lengkap

d. Uraian Kejadian: Berdasarkan informasi awal dari salah satu warga Jl. Gatot Subroto Linkungan Perumtel
Kelurahan Madaatte Kecamatan Polewali, akan ada pembagian uang yang dilakukan oleh salah satu calon anggota DPRD Kabupaten Polewali Mandar Partai Hanura dapil 1 (Satu) bernisial SMR Setelah Bawaslu melakukan penelusuran/investigasi, pada pukul 12:00 Wita, Bawaslu menemukan bukti berupa uang pecahan seratus ribu sebanyak 2 (dua) lembar dari ibu berinisial RMT dan Ibu bernisial MRN selaku penerima dari ibu yang bernisial FT. Selanjutnya Bawaslu melakukan penelusuran/ investigasi untuk kedua kalinya di lokasi yang sama pada pukul 17:00 Wita, Bawaslu menemui FT selaku pemberi. Dan FT mengakui bahwa dia yang memberikan uang kepada Ibu RMT dan Ibu MRN. Dari pengakuan FT ditempat kejadian, mengatakan, bahwa yang memberikan uang adalah saudara bernisial E yang tak lain merupakan anak dari calon anggota DPRD Kabupaten Polewali Mandar Partai Hanura dapil 1 (Satu) atas nama SMR Nomor Urut 4 (Empat), sebanyak Rp. 600.000,00- (Enam Ratus Ribu Rupiah) sudah di bagikan ke ibu RMT dan Ibu MRN. Lalu ibu FT mengatakan, bahwa masih ada sisa Rp.400.00,00- (empat Ratus Ribu Rupiah) karena belum sempat dibagikan ke masyarakat setempat. Pengakuan ibu FT pada saat itu, sebelumnya pada hari Minggu tanggal 14 April 2019, ibu E datang ke sekitar rumah dan menyampaikan bahwa, hari senin akan kembali untuk membawakan uang untuk dibagikan kepada masyarakat sekitar wilayah lingkungan Perumtel.

e. Bukti-Bukti: Uang pecahan seratus ribu sebanyak 6 (enam) lembar dengan nomor seri: WJF 592052; PBM 458165; ZBU 851773; JAO 600136; UES 754880; dan GFE 898258 .

f. Tanggapan Unsur Kepolisian

- Bahwa kasus tersebut tidak cukup bukti untuk ditingkatkan ke tahap penyidikan dan tidak memenuhi unsur pasal yang disangkakan yakni pasal 523 ayat (2) Undang-Undang NOmor 7 Tahun 2017;

- Tidak cukup 2 (dua) alat bukti sehingga kasus tersebut tidak dapat ditingkatkan ke tahap penyidikan;

- Kasus tersebut dihentikan;

g. Tanggapan Unsur Kejaksaan

- Dari hasil klarifikasi terhadap para saksi dan para terlapor belum ditemukan fakta hukum mengenai perbuatan terlapor saudara SMR dan saudarai E yang mengarah kepada perbuatan yang mengarah kepada unsur pasal yang dikenakan kepada terlapor saudari E dan saudara SMR karena tidak adanya ajakan sebagaimana dimaksud dalam pasal 278 ayat (2) Undang-Undang Nomor 7 tahun 2017 tentang Pemilihan Umum;

- Belum adanya keterkaitan antara saudara SMR dan saudari E yang membuktikan perbuatan saudara SMR dan saudari E yang mengarah kepada unsur pasal yang disangkakan kepada para terlapor;

- Perbuatan terlapor saudara SMR dan saudari E belum memenuhi unsur pasal yang dikenakan kepada terlapor;

- Perkara belum dapat dinaikkan ketahap Penyidikan karena belum cukup bukti dan belum memenuhi unsur pasal yang dikenakan kepada para terlapor;

h. Tanggapan Unsur Bawaslu

Saudari E telah memberikan uang kepada saudari FT. Dan saudari FT telah membagikan sebahagian 
dana tersebut. Kejadian ini terjadi pada masa tenang sehingga sangat jelas tujuan pemberian uang tersebut sebagaimana tercantum dalam klarifikasi;

- Dapat dinaikkan statusnya dalam tingkat Penyidikan;

- Memenuhi unsur guna Tindak Pidana Pemilu;

i. Kesimpulan: Perbuatan terlapor Saudara SMR dan Saudari E belum terpenuhi untuk pembuktian dalam pasal 523 ayat (2) Undang-Undang Pemilihan Umum Tahun 2017 sehingga belum dapat ditingkatkan ke tahap penyidikan.

j. Rekomendasi: Perkara belum dapat dinaikkan ketahap Penyidikan karena belum cukup bukti dan belum memenuhi unsur pasal yang dikenakan kepada para terlapor.

c. Kasus Temuan 009/TM/PL/KAB/30.05/IV/2019, diregistrasi pada tanggal 22 April 2019

a. Pasal Disangkakan: Pasal 523 ayat (2) "Setiap pelaksana, peserta, dan/atau tim Kampanye Pemilun yang dengan sengaja pada Masa Tenang menjanjikan atau memberikan imbalan uang atau materi lainnya kepadaPemilih secara langsung ataupun tidak langsung sebagai mana dimaksud dalam Pasal 278 ayat (2) dipidana dengan pidana penjara paling lama 4 (empat) tahun dan denda paling banyak Rp48.000.000,00 (empat puluh delapan juta rupiah)."

b. Syarat Formil: Pelapor, Terlapor, Batas Waktu Temuan (belum daluwarsa), Kesesuaian tanda tangan pada formulir laporan dengan KTP Electronic.

c. Syarat Materil: Peristiwa dan uraian kejadian, Tempat kejadian terjadi, Saksi, Bukti.

d. Uraian Kejadian: Bawaslu Kabupaten Polewali Mandar pada hari Selasa, 16 April 2019 Pukul 21.00 bapak bernisial SA bersama staf Bawaslu Kabupaten Polewali Mandar melakukan patroli pengawasan masa tenang di tiga Kecamatan yakni, Mapilli, Campalagian, Luyo. Dalam Patroli Pengawasan SA memulai perjalanan dari kantor Bawaslu Kabupaten Polewali Mandar menuju tiga kecamatan yakni, Mapilli, Campalagian dan Luyo. Tiba di Kantro Sekretariat Kecamatan Campalagian Panitia Pengawas Desa dan Kelurahan disingkat PPD/Kel bernisial AK, dan PR. Dalam perjalanan SA bersama staf dan PPD/Kel di Kecamatan Campalagian, SA memasuki Desa Parappe, Katumbangan dan Katumbangan Barat. Pada saat SA dan rombongan berada di Kantumbangan Barat, rombongan kemudian menerima telepon dar MYD salah seorang masyarakat Desa Bonde. Melalui MYD diperoleh informasi bahwa telah terjadi tindakan politik uang. Menerima informasi itu, rombongan bersama SA kemudian langsung meluncur ke lokasi di Desa Bonded dan menemukan saudara AR yang diduga melakukan politik uang tengah dikerumuni warga. Sekitar pukul 23.10 Wita AR kemudian dinaikkan ke dalam mobil milik Bawaslu Polewali Mandar. Dalam perjalanannya, AR kemudian mengakui telah melakukan pembagian uang. Mendapati pengakuan itu, rombongan kemudian menuju rumah MR salah seorang warga yang sudah diberikan uang oleh AR berdasarkan pengakuannya. Tiba di rumah MR itu, dari pengakuan MR kemudian diperoleh pengakuan bahwa, benar bahwa betul diberi uang sebanyak Rp. 100.000,00 (Seratus Ribu Rupiah) dalam bentuk pecahan satu lembar disertai ajakan untuk memilih nama, sebagaimana yang ada di dalam contoh surat suara yang juga diserahkan kepada MR. Setelah itu, rombongan kemudian menuju rumah AR di Desa Lagiagi untuk mengambil identitas $\mathrm{AR}$ yang dia tidak bawah, lalu rombonga patroli kemudian menuju ke Kantor Panwaslu Kecamatan untuk mengambil keterangan AR. Berdasarkan keterangan AR dalam bentuk tertulis diakui bahwa, pihaknya sudah membagikan uang tersebut sejak 4 (empat) hari yang lalu, dan dibagikan di Desa Bonde, Pappang, dan Desa Lagiagi. Uang tersebut sebanyak Rp. 5.000. 000,00 (Lima Juta Rupiah) yang diberikan dari Caleg Kabupaten atas nama FDY partai PKS. Uang tersebut di ambil langsung di rumah FDY di Kecamatan Luyo. Sisa uang yang belum dibagikan sebanyak Rp. 300.000,00 (Tiga ratus Ribu Rupiah).

e. Barang Bukti: 1) Uang Pecahan Seratus Ribu sebanyak Empat Lembar dengan nomor seri: HBG 272252; CFZ 983230; BEH 694228; dan XAU 618574. 2) Spesifikasi Surat Suara Pemilihan Umum DPRD Kab/Kota.

f. Tanggapan Unsur Kepolisian

- Bahwa dalam kasus tersebut tidak cukup bukti untuk ditingkatkan ke tahap penyidikan karena hanya ada satu keterangan saksi yang menerangkan perbuatan terlapor dan tidak ada saksi lain yang mendukung keterangannya (berdiri sendiri) sehingga tidak tergambar dengan jelas perbuatan terlapor, apalagi dari keterangan terlapor yang tidak mengakui perbuatannya sehingga kasus tersebut tidak dapat ditingkatkan ke tahap penyidikan

- Tidak cukup 2 (dua) alat bukti

- Kasus tersebut tidak dapat ditingkatkan ke tahap penyidikan sehingga kasusnya dihentikan.

g. Tanggapan Unsur Kejaksaan

- Keterangan saksi saudara Munar, Ruslan, semuanya berdiri sendiri, tidak saling berkaitan sehingga tidak diperoleh alat bukti keterangan saksi

- Terkait video rekaman telah dibantah oleh saudara Arif (terlapor) dan tidak ada saksi yang membuktikan perbuatan (Materil) yang ada dalam video tersebut

- Belum ditemukan alat bukti yang cukup untuk ditingkatkan ke tahap penyidikan

- Perkara belum dapat di tingkatkan ke tahap penyidikan karena belum cukup bukti dan belum memenuhi unsur pasal yang dikenakan kepada para terlapor.

h. Tanggapan Unsur Bawaslu

- Bahwa dinyatakan memenuhi unsur dimana saudara Arif sebagai penerima dana dari saudara Fadilhy (Calon Anggota Legislatif Partai Keadilan Sejahtera dapil 3) adalah peserta kampanye dan pelaksana kampanye, saudara Arif telah membagikan dana kepada warga sehingga dana tersebut tersisa Rp. 300.000,- (tiga ratus ribu rupiah);

- Bahwa memenuhi unsur melakukan bagian Tindak Pidana Pemilu;

- Bahwa dapat dinaikkan ketahap penyidikan.

i. Kesimpulan: Perbuatan terlapor Saudara Fadilhy dan belum terpenuhi untuk pembuktian dalam pasal 523 ayat 
(2) Undang-Undang Pemilihan Umum Tahun 2017 sehingga belum dapat ditingkatkan ke tahap penyidikan.

j. Rekomendasi: Perkara belum dapat dinaikkan ketahap Penyidikan karena belum cukup bukti dan belum memenuhi unsur pasal yang dikenakan kepada para terlapor. Terhadap data yang diperoleh dari Bawaslu Kabupaten Polewali Mandar, utamanya terkait 3 (tiga) kasus politik uang yang ditanganinya pada Pemilu Tahun 2019 ketiganya merupakan temuan hasil pengawasan, yang telah melalui tahap pembahasan yakni pembahasan pertama, merupakan kajian awal Bawaslu Kabupaten Polewali melalui rapat pleno untuk memastikan apakah memenuhi syarat formil dan syarat materil. Fakta menunjukkan, melalui rapat pleno tersebut tiga kasus dinyatakan memenuhi syarat, maka langkah selanjutnya adalah Bawaslu Kabupaten Polewali Mandar mengundang unsur Kejasaan, unsur Kepolisian untuk melakukan pembahsan kedua untuk menentukan terpenuhinya unsur suatu tindak pidana atau tidak.

Dari fakta dokumen pembahsan pada Sentra Penegakan Hukum Terpadu (Sentra Gakkumdu) menunjukkan bahwa, diantara tiga unsur tersebut tidak sependapat mengenai alat bukti. Dimana unsur Kepolisian dan Kejaksaan sependapat bahwa terduga tidak memenuhi unsur perbuatan melawan hukum sebagaimana tercantum dalam Undang-Undang Nomor 7 Tahun 2017 Tentang Pemilihan Umum. Sementara disisi lain, Bawaslu Polewali Mandar telah menyarakan dikapnya, bahwa kasus tersebut telah memenuhi unsur dan dipandang layak untuk ditingkatkan statusnya ke tingkat penyidik Kepolisian Resort Polewali Mandar. Sayangnya, sesuai data yang diperoleh dalam penelitian ini, menunjukkan sikap ambivalen atau mendua, dimana pada akhirnya Bawaslu Kabupaten Polewali Mandar justru mengikuti pendapat Kepolisian dan Kejaksaan yang berpendapat tidak terpenuhinya unsur sebagai tindak pidana politik uang pada tiga kasus yang ditanganinya.

Tetapi pilihan yang diambil oleh Bawaslu Polewali Mandar untuk mengikuti pendapat Kepolisian dan Kejaksaan itu, dikarenakan oleh sistem pengambilan keputusan yang harus melalui rapat pembahasan tahap kedua yang membuat Bawaslu Kabupaten Polewali Mandar harus mengikuti pendapat Kepolisian dan Kejaksaan. Artinya, dapat dikatakan bahwa, mekanisme dalam penentuan terpenuhi tidaknya unsur tindak pidana politik uang sangat tergantung pada analisis dan kajian tim sentra Gakkumdu yang di dalamnya memuat tiga unsur lembaga. Dimana jika salah satu unsur lembaga yang menolak untuk tidak naik ke tingkkan penyidikan, maka ketiga unsur tersebut turut ikut menghentikan pembahsan kasus tersebut ke tingkat pembahasan selanjutnya.

Mekanisme Penyelesaian Tindak Pidana Pemilu Bawaslu Kabupaten Polewali Mandar. Adapun mekanisme penyelesaian tindak pidana Pemilu sebagaimana yang diterapkan oleh Bawaslu Kabupaten Polewali Mandar secara konsisten telah merujuk kepada Peraturan Bawaslu Nomor 31 Tahun 2018 tentang Sentra penegakan hukum terpadu pada pasal 19 sampai dengan pasal 32 bahwa: (1) Penyidik dan Jaksa mendampingi Bawaslu, Bawaslu Provinsi, Bawaslu Kabupaten/Kota, dan Panwaslu LN dalam menerima temuan atau laporan tindak pidana Pemilu.(2) Pendampingan sebagaimana dimaksud pada ayat (1) menggunakan format kelengkapan temuan atau laporan dugaan tindak pidana Pemilu. (3) Pendampingan sebagaimana dimaksud pada ayat (2) untuk melakukan identifikasi, verifikasi, dan konsultasi terhadap temuan atau laporan dugaan tindak pidana Pemilu. (4) Dalam hal temuan atau laporan diterima, Pengawas Pemilu membuat dan mengisi format temuan atau laporan serta memberikan nomor dan memberikan surat tanda penerimaan laporan kepada pelapor. (5) Setelah temuan atau laporan diterima, Pengawas Pemiludidampingi oleh anggota Gakkumdu sesuai tingkatan melakukan klarifikasi terhadap pelapor dan saksi yang hadir. (6) Koordinator Gakkumdu sesuai tingkatan menerbitkan surat perintah Penyelidikan setelah temuan atau laporan diterima Pengawas Pemilu. (7) Penyelidik melakukan Penyelidikan berdasarkan surat perintah Penyelidikan.

Berdasarkan mekanisme dan tata aturan proses penanganan temuan dan laporan, sebagaimana ketentuan Peraturan Bawaslu Nomor 31 tahun 2018 bahwa Bawaslu Kabupaten Polewali Mandar bersama Sentra Gakumdu juga merujuk kepada tahapan pembahasan sebagaimana yang diatur oleh ketetapan peraturan perundang-undangan yakni melaksanakan pembahasan sebanyak 4 (empat kali) sebagai berikut:

3.2. Kendala-Kendala yang Dihadapi dalam Penegakan Hukum terhadap Pelaku Tindak Pidana Politik Uang dalam Pemilu 2019 di Kabupaten Polewali Mandar

\section{a. Struktur Hukum}

Inti dari kegiatan penegakan hukum adalah upaya yang dilakukan untuk menjadikan hukum sebagai pedoman perilaku dalam setiap perbuatan hukum, baik itu oleh para subyek hukum yang bersangkutan maupun oleh aparatur penegak hukum. Aparatur penegak hukum merupakan lembaga resmi yang diberi tugas dan wewenang oleh undang-undang untuk menjamin berfungsinya norma-norma hukum yang berlaku dalam kehidupan masyarakat dan negara. Keberadaan aparatur penegak hukum memang tidak bisa dilepaskan dari proses penegakan hukum. Sebab aparatur penegak hukum itulah yang nantinya akan menegakkan aturan hukum. Apabila aparatur penegak hukum memiliki mental yang buruk, maka akan menciptakan penegakan hukum yang buruk pula.

Sebaliknya, apabila aparatur penegak hukum memiliki mental yang baik dalam menegakkan aturan hukum, maka akan tercipta penegakan hukum yang baik dan bersifat responsif. Agar proses penegakan hukum di Indonesia berjalan secara adil, maka pemerintah Indonesia wajib membangun dan menguatkan mental para aparatur penegak hukum. Uraian data penelitian tentang penegakan hukum politik uang di Kabupaten Polewali Mandar dikaitkan dengan teori Friedman sebagaimana diuraikan pada bab dua, bahwa ada tiga komponen sistem penegakan hukum yakni struktur hukum, subtansi hukum, dan kultur hukum. Struktur dari sistem hukum merupakan bentuk yang permanen dari sistem penegakan hukum terhadap dugaan tindak pidana politik uang pada Pemilu DPR, DPD, Presiden dan Wakil Presiden, serta DPRD yang dilaksanakan lima tahun sekali mengalami perubahan bentuk dan sistem pada strukturnya. Pemilu tahun 2014 dan Pemilu tahun 2019 bahwa penegakan hukum pidana yang pintu satu-satunya proses penegakan hukum adalah pengawas pemilu bersifat ad hoc namun pada tahun 2017 sebagaimana ketentuan UU Nomor 7 Tahun 2017 bahwa Panitia pengawas Pemilu di Kabupaten/Kota berubah menjadi Badan Pengawas Pemilu yang permanen dengan masa tugasnya selama lima tahun. 
Dalam konteks Pemilu struktur adalah aparat penegak hukum ditambah dengan Bawaslu RI, Bawaslu Provinsi, dan Bawaslu Kabupaten/Kota yang tergabung dalam Sentra Penegakan Hukum Terpadu. Struktur Hukum (Sentra Gakkumdu) dalam penegakan hukum tindak pidana pemilu khususnya tindak pidana politik uang dapat dikatakan tidak berjalan optimal. Hal ini dikarenakan dalam proses penegakan hukum tindak pidana pemilu diberi tugas lebih awal untuk melakukan proses penanganan dugaan pelanggaran pemilu, baik itu temuan maupun laporan yang dalam waktu tujuh hari sejak ditemukan dana atau menerima laporan diregistrasi oleh Bawaslu. Jika Bawaslu memerlukan tambahan keterangan dari terlapor, saksi maupun pihak terkait lainnya maka dapat tambahan waktu selama tujuh hari kerja, sehingga total waktu yang diperlukan Bawaslu dalam proses penanganan dugaan pelanggaran adalah 14 hari. Waktu penanganan pelanggaran ini sudah termasuk pembahsan di Sentra Gakkumdu sampai dengan pembahasan kedua untuk menentukan kasus tersebut dapat dilanjutkan ketingkat sidik atau tidak.

Sebagaimana yang terungkap melalui diskusi terarah dalam bentuk focus group discussion (FGD) yang digelar di Kantor Bawaslu Polewali Mandar dimana pihak atau unsur Kejaksaan Negeri Polewali Mandar menyatakan, "mengenai daluwarsa perkara yang tidak bisa dilanjutkan sebelumnya memang sudah ada aturan tersendiri". Di lihat dari segi waktu penanganannya begitu singkat, maka dapat dibayangkan betapa berat terbatasnya bagi Bawaslu dalam melaukan pembuktian mulai dari investigasi dilapangan mencari alat bukti, melakukan klarifikasi terhadap terlapor dengan mekanisme melalui surat undangan (Panggilan) kepada terlapor untuk datang di Kantor Bawaslu untuk dilakukan klarifikasi, disinilah kendalanya bahwa beberapa terlapor tidak memenuhi undangan untuk klarifikasi sehingga mekanisme pemanggilan sebanyak tiga kali, jika terlapor teteap tidak memenuhi panggilan, maka waktu penanganan akan memasuki masa daluwarsa di mana Bawaslu tidak punya kewengan untuk melakukan pemanggilan Paksa.

Jika Bawaslu dan jajarannya sampai ke tingkat Pengawas di Kecamatan disingkat Panwascam, Pengawas di Desa dam Kelurahan (PPD/Kel), dan Pengawas TPS, digolongkan sebagai struktur hukum, maka disini juga terdapat kelemahannya dari segi waktu perekrutan termasuk untuk melakukan peningkatan kapasitas peningkatan sumber daya manusianya (SDM). Terkait dengan SDM, pihak atau unsur Kejaksaan Negeri Polewali juga mengaku, kadang kesulitan apabila kita kekurangan SDM menghadapi masalah- masalah seperti ini dan tentunya. Karenanya kita harus saling bekerjasama dengan baik. Dari segi penegakan hukum tindak pidana politik uang yang lain perlu diperhatikan adalah struktur hukum di Sentra Penegakan Hukum terpadu yang terdiri dari unsur Bawaslu, Kepolisian, dan Kejaksaan. Disentra Gakumdu inilah sangat memegang peranan dalam menagani proses dugaan pelanggaran terhadap tindak pidana politik uang atau tindak pidana pemilu lainnya. Dalam analisis penulis bahwa yang paling memegang peranan terkait struktur hukum di sentra Gakkumdu adalah Kejaksaan dan Kepolisian.

Peran Kejaksaan dan Kepolisian sebagai struktur hukum yang merupakan penegak hukum yang akuntabel juga menyangkut the scientific of legal problem, untuk itu kejaksaan dan kepolisian yang memang merupakan elemen negara dalam penegakan hukum yang sudah professional dan memiliki instin yuridis yang tajam dalam segala kebutuhan masalah hukum dan menyelesaikannya secara cepat, tepat, adil dalam rangka mewujudkan penegakan hukum terhadap tindak pidana politik uang dan tindak pidana lainnya. Dalam konteks penegakkan hukum tindak pidana politik uang di Kabupaten Polewali Mandar pada Pemilu tahun 2019, fakta penelitian mengungkapkan bahwa Struktur hukum yang tegabung dalam Sentra Penegaakan Hukum Terpadu adalah dari tiga kasus dugaan Politik Uang terdapat perbedaan pandangan dan pendapat terkait dengan terkait dengan alat bukti diantara stuktur hukum tidak sepakat yang akhirnya kasus tersebut tidak dapat ditingkat ketingkat penyidik di Kepolisian.

Berdasarkan Teori Lauwrence M. Friedman tentang sistem hukum, khususnya tentang struktur hukum dalam analisa penulis terhadap hasil kajian pustaka terhadap dokumen Bawaslu Polewali Mandar pada pembahasan pertama dan kedua dalam tim Sentra Gakkumdu menunjukkan bahwa, betapa lemahnya struktur hukum di mana terdapat 3 (tiga) kasus politik uang namun taksatupun yang ditindak lanjuti ke tingkat penyidikan Kepolisian. Terkait struktur hukum dalam penelitian ini penulis telah berkesimpulan bahwa ada beberapa kendala sebagai berikut:

a. Struktur Bawaslu yang tidak berjalan efetif terutama keterbatasan suberdaya pengawasan ditingkat Kecamatan, Desa/Kelurahan, dan Pengawas TPS yang sangat terlambat pembentukannya dan keterbatasan personil yang direkrut berpengaruh pada Sumberdaya Manusia.

b. Bawaslu dalam melakukan pembuktian terhadap perbuatan yang diduga melanggar ketentuan hukum tetntang pemilu sangat lemah sehingga pembahasan di sentra gakumdu tetap tidak bisa naik sidik dikepolisian karena terjadi ketidak sepahaman diantara anggota gakumdu terutama pada pihak kejasaan.

c. Belum Optimalnya peran sentra gakumdu, di mana tujuan dibentuknya Sentra Penegakan Hukum Terpadu adalah untuk menyamakan pemahaman pada pola penanganan tindak pidana pemilu khusnya yang dalam penelitian ini adalah tindak pidana politik uang.

\section{b. Subtansi Hukum}

Substansi Hukum diartikan sebagai norma, dan pola perilaku nyata manusia yang berada dalam sistem itu. Substansi diartikan pula sebagai produk yang dihasilkan oleh orang yang berada dalam sistem hukum itu, termasuk keputusan yang mereka keluarkan maupun yang akan disusun. Dalam konteks Pemilu yang termasuk dalam substansi adalah UUD 1945, Undang-Undang Nomor 7 tahun 2017 tentang Pemilihan Umum. Substansi hukum dapat dikatakan sebagai salah satu faktor yang memberikan kontribusi terhadap dua belas kasus tindak pidana Pemilu di Kabupaten Polewali Mandar pada tahun 2019 tiga diantaranya adalah kasus politik uang. Banyak kasus tindak pidana Pemilu terjadi karena lemahnya substansi hukum. Lemahnya substansi hukum, terjadi karena disengaja ataupun tidak disengaja.

Cara sederhana, menjadikan norma hukum yang tidak jelas atau kabur. Substansi hukurn yang tidak jelas bukan hanya mudah untuk melakukan tindak pidana Pemilu, tetapi juga memberikan kesempatan yang luas untuk aparat penegak hukurn untuk mempermainkan atau merekayasanya sesuai dengan kepentingannya masing-masing. Untuk hal ini, berdasarkan pandangan Bawaslu Kabupaten Polewali Mandar sebagaimana yang terungkap melalui FGD dikatakan bahwa, 
salah satu alasan politik uang ini masuk tindak pidana Pemilu karena tiga hal sebagai berikut:

a. Pemberi berupaya untuk mempengaruhi salah satu calon pemilih untuk tidak menggunakan hak pilihnya

b. Pemberi berupaya untuk mempengaruhi calon pemilih untuk menggunakan hak pilihnya dengan hal hal tertentu

c. Pemberi berupaya untuk mempengaruhi calon pemilih untuk menggunakan hak pilihnya untuk memilih calon.

Bagi penegak hukum yang bekerja demi kepentingan penegakan hukum, aturan yang tidak jelas dapat digunakan untuk menjerat pelaku tindak pidana Pemilu yang memanfaatkan aturan hukum yang tidak jelas itu. Sementara bagi penegak hukun yang ingin meraih keuntungan finansial, substansi hukum yang demikian akan diperdagangkan dengan mereka yang tersangkut kasus tindak pidana politik uang pada pemilu.

Substansi hukum (legal substance) dapat dikatakan sebagai salah satu faktor yang memberi kontribusi besar terhadap banyaknya tindakpidana Pemilu di kabupaten Polewali Mandar. Hal itu terjadi karena substansi hukum direkayasa untuk memudahkan melakukan tindak pidana Pemilu. Tidak hanya itu, substansi hukum juga dirancang sedemikian rupa sehingga memudahkan mereka yang tersangkut dugaan tindak pidana Politik uang untuk mengelak dari jeratm hukum. Cara paling sederhana, membuat norma hukum yang tidak jelas atau kabur, sebagai contohnya soal difinisi kampanye yang harus terpenuhi unsus-unsurnya secara kumulatif.

Tabel 1.

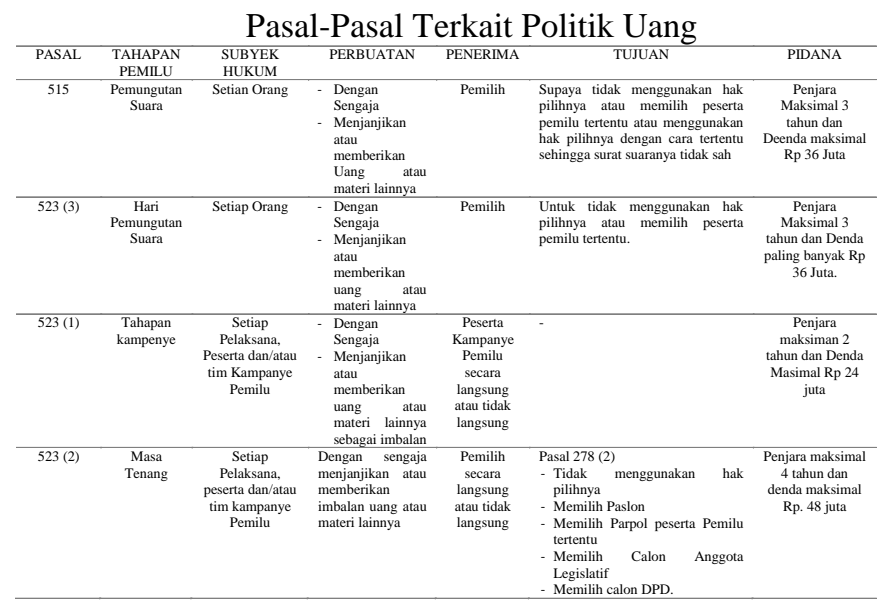

Untuk memperjelas pemahaman diseputar subtansi hukum, maka berikut ini dijelaskan dalam bentuk tabel yang memuat pasal-pasal yang terkait dengan politik uang sebagai berikut:

a. Batasan Waktu Bagi Bawaslu dan Aparat Penegak

Hukum Dalam melakukan penanganan pelanggaran dan tindak lanjutnya.

Sebagaimana diuraikan dalam Bab II poin 4 tentang pola penaganan tindak pidana pemilu terdapat ketentuan yang mengatur tentang waktu penangan dugaan tindak pidana pemilu. Pada tahap proses penanganan dugaan tindak pidana pemilu Bawaslu telah memiki waktu 7 (tujuh) hari sejak diketahui dana tau ditemukan pelanggaran pemilu dan Bawaslu telah melakukan investigsi, klarifikasi, dan kajian awal atas temuan dan laporan dugaan pelanggaran pemilu. Pada prakteknya batasan waktu ini jika Bawaslu memerlukan tambahan keteraangan maka Undang-Undang memberi ruang menambah 7 (tujuh hari lagi untuk melakukan proses penanganan dugaan pelanggaran pemilu, sebagaimana diatur dalam pasal 454 ayat 5 dan 6 Undang-Undang nomor 7 Tahun 2017 Tentang Pemilu. Total dugaan pelanggaran pidana pemilu yang ditangani oleh Bawslu Kabupaten Polewali Mandar pada pemilu 2019 sebanyak 12 kasus 3 (tiga) diantaranya adalah pidana politik uang. Dari total kasus yang diproses oleh Bawaslu Kabupaten Polewali Mandar ada 1 (satu) kasus yang telah diproses di Pengadilan Negeri Polewali yang diputuskan bersalah dan di jatuhi hukuman Penjara selama 4 (empat bulan) penjara dan denda lima juta rupiah (Rp. 5.000,000) , kasus tersebut terkait dengan mencolos dua kali di TPS yang berbeda dengan menggunakan identitas orang lain karena yang bersangkutan melanggar pasal 533 Undang-Undang Nomor 7 tahun 2017 Tentang Pemilu. (Nomor putusan: 86/Pid.Sus/2019/PN.Pol).

Tiga kasus politik uang tidak ditindak lanjuti dengan alasan bahwa pihak kejaksan dan kepolisian disentra Gakumdu berdalih bahwa kasus tersebut tidak memenuhi unsur formil dan materil sebuah dugaan tindak pidana pemilu sesuai dengan perturan dan perundang-undangan yang berlaku, bagi Bawaslu berdalih bahwa kasus politik uang tersebut telah memenuhi unsur formil dan materil dan yang paling urgent bagi bawaslu dalam menangani duagaan tindak pidana politik uang adalah terkendala dari segi waktu penanganannya yang mencakup:

1. Penentuan bukti yang cukup

2. Pengumpulan barang bukti

3. Keterpenuhan unsur-unsur suatu delik pidana

4. Identifikasi pelapor, terlapor, dan saksi.

Disisi lain Bawaslu tidak berwenang untuk menyita barang bukti dugaan tindak pidana pemilu. Tidak terpenuhinya syarat formil dan materil suatu laporan tindak pidana pemilu, mengakibatkan Bawaslu kesulitan untuk menindak lanjuti suatu laporan, syarat materil salah satunya adalah mencari saksi-saksi sehingga hasil kajian terkadang tidak lengkap. Sedangkan untuk tahapan berikutnya adalah Bawaslu, Kepolisian, dan kejaksaan melakukan pembahasan peratama dan kedua untuk menetukan terpenuhi tidaknya unsur tindak pidana pemilu.

Dalam tahapan pembahsan kedua dalam fakta dokumen yang dimiliki Bawaslu bahwa Bawaslu telah berdali bahwa kasus tersebut telah memenuhi syarat formil dan materil, namun terutama dari pihak Kejaksaan berpendapat belum terpenuhi syarat materil dan syarat formil suatu tidak pidana, pendapat ini telah diaamini oleh pihak kepolisian. Bawaslu dalam melakukan investigasi untuk mencari barang bukti telah didampingi oleh pihak kepolisian, termasuk Bawaslu dalam melakukan kalrifikasi/meminta keterangan juga didamping kepolisian yang tergabung dalam sentra gakumdu. Jika dikaji lebih dalam lagi penulis penulis menganalisa mengapa pembuktian selalu sulit dipemabahasan kedua di Sentra Gakumdu, semestinya sebelum memasuki pembahasan seharusnya barabg bukti dan alat bukti sudah harus lengkap karena Bawaslu dan kepolisian sudah melakukan investigasi bersama di tempat kejadian perkara. Dalam penelitian penulis telah menemukan suatu kelemahan disentara Gakumdu dalam menetukan status laporan ataupun temuan yakni bahwa keanggotaan Sentara Gakumdu terdiri dari tiga unsur, seharusnya dalam menentukan status dugaan tindak pidana pemilu tersebut melakukan voting, namun hal ini tidak terjadi bahwa jika salah satu unsur dari sentra gakumdu tidak setuju, maka pembahsan berikutnya dihentikan. Dihentikannya pembahasannya kasus dugaan tindak pidana pemilu tersebut adalah berbias negative kepada lembaga Bawaslu yang dipandang oleh masyarakat bahwa Bawaslu dalam melaksanakan tugas tidak professional, sementara itu yang tidak sepakat adalah dari salah satu unsur di luar Bawaslu. 
b. Lemahnya Ketentuan Undang-Undang tentang politik uang.

Ketentuan Undang-Undang Nomor 7 Tahun 2017 Tentang Pemilihan Umum memungkinkan terjadinya politik uang, misalnya politik uang dilakukan pada masa tahapan kampanye, jika dilihat defenisi kampanye sebagaimana disebutkan pada pasal 1 poin 35 Undang-Undang Nomor 7 Tahun 2017 Tentang Pemilihan Umum berbunyi “ Kampanye Pemilu adalah kegiatan peserta Pemilu atau pihak lain yang ditunjuk oleh Peserta Pemilu untuk meyakinkan Pemilih dengan menawarkan visi, misi, program dan/atau citra diri Peserta Pemilu". Dari pengertian kampanye tersebut unsur kampanye bersifat kumulatif, dengan demikian salah satu unsur tidak terpenuhi pengawas pemilu tidak bisa menjerat adanya pelanggaran pemilu.

Dalam kasus politik uang yang dilakukan oleh peserta pemilu atau caleg pada saat melakukan penyerahan barang berupa uang dan/atau materi lainnya kepada pemilih tanpa disertai dengan penyampaian visi, misi, atau tidak mengeluarkan kalimat ajakan untuk memilih, tidak bisa dikategorikan sebagai pelanggaran aturan kampanye. Kepolisian dan/atau Kejaksaan dalam menangani tidak pidana pemilu oleh Undang-Undang nomor 7 tahun 2017 Tentang pemilihan Umum, tidak diberi kewenangan untuk melakukan penahanan terhadap tersangka/terdakwa dugaan pelanggaran pidana pemilu. Misalnya jika tersangka tidak hadir dalam penyidikan dikepolisian atau bahkan melarikan diri dan baru muncul setelah waktu penanganan lewat setelah kasus tersebut dilimpahkan ke-kepolisian oleh Bawaslu, maka kepolisian tidak bisa menindak lanjuti karena kasus tersebut sudah daluwarsa.

Unsur ketiga dalam sistem penegakan hukum adalah budaya hukum. Budaya hukum yaitu sikap manusia terhadap hukum dan sistem hukum meliputi kepercaan nilai, pemikiran serta harapan. Budaya hukum meliputi pula suasana pikiran sosial dan kekuatan sosial yang menentukan bagaimana hukum digunakan, dihindari atau disalahgunakan. Budaya hukurn erat kaitannya dengan kesadaran hukurn masyarakat. Semakin tinggi kesadaran hukum masyarakat maka akan tercipta budaya hukum yang baik dan dapat merubah pola pikir masyarakat mengenai hukum selama ini. Secara sederhana, tingkat kepatuhan masyarakat terhadap hukum merupakan salah satu indikator berfungsinya hukum. Tanpa budaya hukum sistem hukum itu sendiri tidak akan berdaya, Friedman mengibaratkan ini seperti ikan mati yang terkapar di keranjang, bukan seperti ikan hidup yang berenang di laut. Setiap masyarakat, setiap negara, setiap komunitas mempunyai budaya hukum, selalu ada sikap dan pendapat mengenai hukum.

Masyarakat Kabupaten Polewali Mandar sendiri belum terlalu paham dan patuh dengan proses penegakan hukum yang ada. Pelaksanaan penegakan hukum terhadap tindak pidana Pernilu di Kabupaten Polewali Mandar belum optimal dan adil. Ada keengganan masyarakat untuk melaporkan dugaan tindak pidana Pemilu di Kabupaten Polewali Mandar. Begitu yang terungkap melalui FGD yang disampaikan oleh Bawaslu Kabupaten Polewali Mandar yang mengatakan, pembuktian kasus politik uang susah, karena ada kecemasan yang terjadi dalam hal pelaporan kasus, kadangkala ada yang mengerti dan paham aturan, tapi mereka tidak melaporkan kasus yang mereka dapatkan.
Masyarakat cenderung mentolerir dan mendiamkan saja terjadinya tindak pidana Pemilu dengan alasan merasa enggan berwusan dengan proses hokum yang rumit dan panjang. Bahkan di beberapa Kecamatan masyarakat menganggap tindak pidana Pemilu bukan merupakan sebuah tindak pidana Pemilu, contohnya politik uang. Sebagian masyarakat menganggap money politics adalah sesuatu yang lumrah dan biasa dalam setiap pelaksanaan Pemilu bahkan dianggapnya sebuah rejeki yang setiap lima tahun datang sekali.

Sebagimana yang diungkapkan oleh salah satu tokoh seni budaya Kabupaten Polewali Mandar yang menyatakan bahwa. Keengganan masyarakat melaporkan fakta yang terjadi disekitarnya terkait politik uang dikarenakan, adanya anggapan bahwa uang atau barang yang diberikan oleh para calon itu adalah rejeki yang semestinya tidak harus ditolak oleh masyarakat. Padahal semestinya masyarakat memiliki kesadaran bahwa, leluhur mereka tidak pernah mengajarkan untuk menerima uang atau barang dalam bentuk apapun jika itu akan terkait dengan hubungan kepentingan untuk kepemimpinan. Ada juga budaya masyarakat yang cenderung tidak mau melaporkan dugaan pelanggaran tindak pidana Pemilu Legislatif karena takut akan intimidasi dan tindak kekerasan oleh oknurn partai politik atau tirn sukses caleg. Beberapa kasus pelapor dugaan tindak pidana Pemilu tidak mendapatkan perlindungan yang cukup terhadap intimidasi dan tindak kekerasan oleh oknurn partai politik atau tim sukses caleg. Sebagian masyarakat tidak rnau melaporkan dugaan tindak pidana Pemilu karena tidak mau berurusan dengan proses hukum yang panjang dan rumit. Mereka tidak mau repot menghabiskan waktu, tenaga, biaya, dan pikiran untuk mengikuti proses hukum tindak pidana Pemilu. Bahkan beresiko terhadap dirinya sendiri.

Berdasarkan pengakuan dari akademisi melalui wawancara, terungkap bahwa, Menurut pemahaman saya, sejak tahun 2011 sampai dengan saat ini, saya menduga bahwa, sebagian pelapor tindak pidana Pemilu lebih diakibatkan oleh alasan persaingan dalam perolehan suara atau kursi. Artinya pelapor bersedia melapor acapkali lebih dikarekanan oleh, adanya kepentingan tertentu yaitu kepentingan persaingan partai politik atau persaingan antar Caleg. Dalam beberapa kasus hal tersebut memang terbukti berlatar belakang persaingan. Hal tersebut dengan tujuan menjatuhkan partai politik dan Caleg tertentu serta memenangkan partai dan caleg yang didukungnya. Tidak pidana Pemilu dari tiap periode menjadi sebuah perilaku hukum yang negatif dan dilakukan terus menerus di masyarakat. Untuk mengubah budaya hukum tersebut, kita hams memahami nilainilai, tradisi, kebiasaan, sikap dan aspek hidup masyarakat. Dibutuhkan keseriusan dari semua stakeholder untuk mengajak dan mendidik masyarakat dalam mencegah dan menegakkan hukum terhadap tindak pidana Pemilu di Kabupate Polewali mandar.

Kengganan masyarakat untuk melaporkan dugaan tindak pidana pemilu khusnya politil uang jika dilihat dari kasus politik uang yang ditangani Bawaslu Kabupaten Polewali Mandar hanya berjumlah 3 (tiga) kasus sementara dimasyarakat telah menjadi perbincangan yang seolah-olah bukan rahasia lagi bahwa telah banyak peserta pemilu ataupun caleg yang telah melakukan politik uang tetapi pengawas pemilu sulit mendapatkan pelaku dikarenakan begitu rapai dilakukan. Dari fakta ini bahwa penulis telah berpendapat bahwa masyarakat tidak memiliki kesadaran hukum untuk 
melaporkan seitiap dugaan pelanggaran pidana politik uang. Perbuatan politik uang yang menjadi perbincangan umum di masyarakat ibarat orang yang kentut baunya ada tapi wujudnya tidak Nampak inilah yang maembuat pengawas pemilu kesulitan menjerat dan mengungkap pelaku tindak pidana politik disetiap pelaksanaan pemilu maupun pemilihan kepala daerah.

Adapun masyarakat yang enggan melapor disebakan belum maksimalnya perlindungan pelapor dari intimidasi dan tindak kekerasan oleh oknum pesetra pemilu adalah fakta pada saat dilakukan pengawasan patrol di masa tenang oknum yang melakukan pembagian uang, tertangkap langsung oleh Pengawas Pemilu dan malam itu juga dilakukan investigasi dan yang bersangkutan mengakui perbuatannya dan menyerahkan barang bukti untuk diamankan terlebih dahulu. Pada proses klarifikasi oleh Bawaslu Kabupaten Polewali Mandar terduga atau pelaku mengingkari apa yang telah diakui pada saat investigasi tersebut. Kejadian ini oleh penulis membuktikan bahwa kelemahan oleh Bawaslu ataupun Sentra Gakkumdu tidak mempunyai kewenangan untuk melakukan Penahanan.

Ketidaksediaan masyarakat menjadi pelapor dan saksi dugaan pelanggaran tindak pidana politik uang menandakan bahwa kesadaran masyarakat untuk ikut berpartipasi masih lemah, terbukti dari 12 (dua belas) kasus yang diproses Bawaslu Kabupaten Polewali Mandar, 3 (tiga) diantaranya adalah politik uang semuanya adalah temuan Bawaslu.

\section{KESIMPULAN DAN SARAN}

Kesimpulan dalam penelitian ini adalah bentuk penegakan hukum terhadap pelaku tindak pidana Politik Uang dalam pemilihan Umum tahun 2019 di Kabupaten Polewali Mandar dilakukan sesuai peraturan perundang-undangan yang berlaku. Proses dan mekanisme penanganan terhadap 3 (tiga) dugaan tindak pidana politik uang yang terjadi menurut Sentra penegakan Hukum Terpadu (Gakumdu) telah memenuhi syarat tindak pidana pemilu sebagaimana diatur UndangUndang Nomor 7 tahun 2017, berupa politik uang. Kemudian dilanjutkan penyidikan oleh kepolisian. Akan tetapi kejaksaan Negeri Polewalimenolak bahwa perkara itu belum memenuhi unsur tindak pidana terutama karena tidak ada alat bukti keterangan ahli. Gukumdu kesulitan dalam mencari alat bukti berupa keterangan ahli sebagaimana selalu diminta oleh kejaksaan, apabila berkas perkara tindak pidana pemilu dilimpahkan oleh penyidik kepolisian ke kejaksaan. Hal ini terjadi pada 3 (tiga) perkara tindak pidana pemilu yang menulis sedang teliti.

\section{DAFTAR PUSTAKA}

Afrizal, 2017, Metode Penelitian Kualitatif Sebuah Upaya Mendukung Penggunaan Penelitian Kualitatif Dalam Berbagai Disiplin Ilmu, PT. Raja Grafindo Persada, Depok.

Baso Madiong, , 2019, Sosiologi Hukum (Suatu Pengantar), SAHMedia, Makassar.

https://baranusasetiowordprescom.wordpress.com/2016/02/27

https://polewalimandarkab.bps.go.id/dynamictable/2015/11/18 134/jumlahpenduduk-miskin-di-kabupaten-polewalimandar-2005-2019.html

https://reformasikuhp.org/abolisi-pidana-kurungan-dalamrkuhp-pengaruh-dan-akibatnya/ diakses Pebruari 2021: 20.32 WITA. https://www.google.com/search?q=sanksi+denda+adalah\&oq $=$ sanksi+denda\&aqs=chrome.. Diakses 11 Pebruari 2021: 20.40 WITA

https://www.kompas.com/skola/read/2020/12/17/145445369/h akikat-perlindungan-hukum-dan-penegakan-hukum.

Kitab Undang-Undang KUHPer, KUHP, KUHAP. Cet. 12 Januari 2020, Garaha Medea Pres, tanpa tempat.

Lawrence M. Fridman. 1975, Diterjemahkan oleh M. Khozim dari Buku The Legal System. Nusa Media, Bandung.

Lawrence M. Friedman,2001, American Law an Introduction: Hukum Amerika Sebuah Pengantar, (diterjemahkan oleh Wishnu Basuki). Tata Nusa Jakarta.

Marwan Mas. 2014. Pengantar Ilmu Hukum. Ghalia Indonesia, Bogor

Marwan Mas. 2018. Hukum Konstitusi dan Kelembagaan Negara. Rajawali Pers, Depok.

Muhammad Taufiq, 2014 Keadilan Substansial Memangkas Rantai Birokrasi Hukum, Pustaka Pelajar Yogyakarta.

Saputro, R. E., Madiong, B., \& Siku, A. S. (2019). Fungsi Polisi Dalam Penatalaksanaan Cyber Crime Di Polisi Daerah Sulawesi Barat. Indonesian Journal of Legality of Law, 1(2), 71-75.

Unang-Undang Pemilihan Umum nomor 7 Tahun 2017. Sinar Grafika, 2017. Jakarta

Undang-Undang Dasar 1945. 2002. Sinar Grafika, Jakarta. 